\title{
Somatic Montage for Immersive Cinema
}

\author{
CLEA VON CHAMIER-WAITE \\ Clea T.Waite Studio, Colorado, USA / Berlin, Germany; email: cleawaite@gmail.com
}

Commentary by SZILVIA RUSZEV

\begin{abstract}
Keywords: Immersive cinema, Somatic montage, 20th-century avant-garde, Modernism, Relativity theory, N-dimensional geometry, Montage, Sergei Eisenstein
\end{abstract}

The formal, cinematic language specific to immersive motion pictures is an area of cinema theory that has been neglected up until now. This paper investigates a new language of cinematic montage specific to immersive cinema, somatic montage, while it examines historical precedents in the sciences, arts, and cinema of the twentieth century. We propose somatic montage as a model for developing new poetic structures in time-based works that inhabit a threedimensional, architectonic space - a space of embodiment, motion, perception, and participation in the reception of a work of art. In this paper, we consider cinema as a four-dimensional artwork conceptually engendered by the principles of hyper-dimensions, the outgrowth of scientific discoveries made at the turn of the twentieth century. The expanded cinema mediums of fulldome cinema, immersive video and film installation, virtual reality, and extended reality, when approached as four-dimensional cinema space, allow for a spatialized, non-linear juxtaposition of the cinematic elements. Somatic montage is presented here as an extended, supradimensional notion of what Sergei Eisenstein called the 'disjunctive method of narration'.

\section{Introduction}

The development of a formal, cinematic language for immersive motion pictures is currently in its early stage, a stage comparable to the invention of rhythmic montage pioneered by filmmaker and theorist Sergei Eisenstein, by the early Soviet cinema movement, and by the avant-garde cinema of the 1920s. Immersive cinema affords a proprioceptive interaction of form and content, allowing the signification structure of a film to extend outwards from its internal narrative structure into the architectonic geometry of its projection space. Somatic montage ${ }^{1}$ is a new approach to the established cinematic language of montage that marries chronological with spatial composition in the creation of narrative, presented here as an extended, supra-dimensional notion of what Eisenstein called the 'disjunctive method of narration'. The expanded cinema mediums of fulldome cinema, immersive video and film installation, virtual reality, and extended reality, when approached as architectonic spaces

1 The nomenclature 'somatic montage' was first introduced by this author in 'The Cine-poetics of Fulldome Cinema' (Chamier-Waite, 2013). Portions of this paper are reproduced from the unpublished dissertation Somatic Montage: Supra-Dimensional Composition in Cinema and the Arts (Chamier-Waite, 2019) 
occupied by the immersive motion picture, allow for a spatialized, non-linear juxtaposition of the cinematic elements or 'cells'. Immersive cinema forms a four-dimensional, navigable cinematic space in which the montage composition becomes an embodied, participatory experience. The projection architecture becomes an ordering element in the compositional flow of the film, an element of the cinematic grammar that allows the spectator to construct an interpreted field of associations and meaning in the creation of a poetic narrative.

Art historian Linda Dalrymple Henderson has written a comprehensive treatise ${ }^{2}$ on the profound role that concepts of $n$-dimensional geometry, hyperspace, non-Euclidean geometry, and the fourth dimension played in the development of the avant-garde at the turn of the last century; these were all scientific discoveries that inspired new artistic approaches to space-time, motion, and the faceting of perspective. The concept of somatic montage extends this artistic evolution to the immersive moving image, taking the tesseract, the four-dimensional cube, as a model-metaphor for time-based forms of composition that derive from the deconstruction of linear sources, allowing for a multidimensional re-composition of the parts that actively engages the viewer in constructing associative flow structures.

In this paper, we examine the theoretical underpinnings and artistic experiments beginning with Sergei Eisenstein's theoretical approaches to film montage, leading up to the contemporary moving-image as a supra-dimensional medium. 'Supra-dimensional', from the Latin supra meaning 'above, beyond; transcending', connotes a number of dimensions of space-time greater than those which are characteristic for a given medium. ${ }^{3}$

\section{New Concepts of Space and Time}

New concepts of space in the arts grew out of the discovery of new geometries and physical laws at the turn of the last century. These discoveries fundamentally altered contemporary culture's relationship to space and time by ushering in the validity of notions such as the curvature of space, hyper-dimensions, indeterminacy, and subjectivity as rational principles. These new notions of reality, engendered by the discoveries of non-Euclidean geometry, the Theories of Relativity, and quantum mechanics in the early twentieth century - the 'new science', affected the development of Modernist concepts in the arts from the traditional avant-garde of the early century to Minimalism in the 1960s and '70s.

At the end of the nineteenth century, a great deal of cultural interest sprang up around the concept of $n$-dimensional geometry, hyperspace, and the fourth dimension. Two strands of interpreting the fourth dimension developed: one which defined the fourth dimension as an additional dimension of space perpendicular to our own three, unimaginable to us yet encompassing our three-dimensional scope as the cube encompasses the square; the other defining the fourth dimension as time, imagining space-time as a continuous, four-dimensional volume of past and future spread along a linear axis of time. In this strand, all moments exist simultaneously with the present, constituting a continually shifting, three-dimensional slice of this hyper-solid through our lower-dimensional space.

The dawn of twentieth-century science brought with it, in addition to the invisible dimensions of four-space and beyond, a curved universe in which the familiar rules of Euclidean geometry no longer apply, contradicting the notion of single-point perspective. A relativistic, space-time continuum that undermines the notion of objective truth was also introduced, put forth by physicist Albert Einstein and mathematician Hermann Minkowski. Further developments in physics added the concept of multiple, simultaneous realities, exemplified by quantum-mechanics and physicist Werner

2 See The Fourth Dimension and Non-Euclidean Geometry in Modern Art (Henderson, 1983).

3 'Supra-' as defined in (New Oxford American Dictionary 2011). 
Heisenberg's uncertainty principle. These 'advanced'notions imply an ambiguity to reality far removed from our everyday experience of the world - one that we are still learning to comprehend more than a hundred years later.

These profound new discoveries have resonated with creative artists and intellectuals since their inception at the turn of the last century. The cultural impact of these ideas instigated a Modernist series of artistic and philosophical movements encompassing painting, sculpture, music, literature, cinema, and architecture. Starting with Cubism, Futurism, Dada, and avant-garde cinema, we can follow these influences in the Modernist literature of Joyce, the twelve-tone music of Schoenberg, and the Minimalism of the 1960s. These avant-garde movements share a formal engagement with breaking the singular point-of-view through the disruption of linear narrative, single-point perspective, and spatio-temporal continuity. Motion, fragmentation, simultaneity, ambiguity, and participation with the work of art are constructs that are indicative of Modernism.

The contemporary immersive, expanded, and post-cinematic moving images that developed out of this new space-time concept occupy a critical space among film and media theory, art history, and the history of science. Immersive cinema integrates traits informed by the new science: notions of spatial and temporal ambiguity; poly-perspectival spaces; the interaction of cinema with substance and architecture; the abandonment of determinism, the introduction of relativistic, subjective correspondences; and the participatory role of the spectator in an unfolding narrative.

\section{Hyperspace}

In hyperspace, the simultaneity of space is conjoined with the succession of time. Architect and designer Claude Fayette Bragdon played a key role in popularizing the fourth dimension at the turn of the twentieth century. Bragdon was intrigued by the notion of a supra-dimensional object that is perceivable only in time and then only partially, that is, an object which contains time within its own volume - the four-dimensional hypercube or tesseract. As Bragdon writes: 'Now the characteristic of time is succession; in time alone one thing follows another in endless sequence. The unique characteristic of space is simultaneity, for in space alone everything exists at once' (Bragdon, 1915: 66). When one does perceive the tesseract, time and space, as well as inside and outside, become interchangeable.

The Cubists aspired to portraying a perceived representation over an observed one. The historian of architecture Sigfried Giedion, in Space, Time, and Architecture (1941), analyzes the Cubist rejection of single-point perspective: 'Cubism breaks with Renaissance perspective. It views objects relatively: that is from many points of view, no one of which has exclusive authority. And in so dissecting objects it sees them simultaneously from all sides - from above and below, from inside and outside' (Giedion, 2009: 436). Giedion's analysis brings into focus the implication of observer motion and simultaneous interiority/exteriority in Cubism that also features in Bragdon's description of the tesseract.

The Cubist rejection of Renaissance perspective in favour of a multi-point, -faceted perspective embraced a notion of spatial unfolding, compressing multiple dimensions of space-time onto the two-dimensional image plane. In conventional cinema, this notion of unfolding can be realized as spatial montage, first characterized by media theorist Lev Manovich, as the presentation of multiple, simultaneous, two-dimensional time-based cells distributed across a plane to form a three-dimensional, space-time network of associations. A Cubistic, immersive cinema space is formed that extends beyond the image plane.

The twentieth-century avant-garde movements can be seen as the forebearers of somatic montage in contemporary cinema. Somatic montage explores the concept of montage in the visual arts, poetry, and literature, but especially in cine-installation and immersive cinema as a formal construct rooted in the notions of juxtaposition, cells, and collision developed by Sergei Eisenstein and the 
Soviet cinema. In immersive cinema space, the supra-dimensional tesseract model allows this spatial montage to unfold from the fourth dimension into the third so that the space-time cells are faceted within a three-dimensional space. In a somatic montage, the film is physically distributed throughout an architectural or virtual theatre. The scenes occupy different spatial as well as temporal locations as an added dimension of montage. Immersive cinema affords expanding the signification structure of a film from its internal narrative out into a navigable projection space.

\section{Immersive Cinema}

Immersive cinema is a spatially and sensorily enveloping cinematic experience. In an immersive cinematic experience, the third dimension of real space is enfolded into the scenographic mise-en-scène, dissolving the boundary between the architectonic 'theatre' and the virtual projection spaces to establish a poetic space of mixed reality. Immersive cinema ranges from early panoramic cinema spectacles to the mind-expanding conceptual sweep of'expanded cinema' introduced by Gene Youngblood and the counter-culture movement of the 1960s; multi-projection architectonic video art installations; frameless hemispherical projections; the full, 360-degree spherical, stereoscopic image space of virtual reality; the merging of virtual and real space in mixed reality; and the current technological innovations in giant screen and immersive formats that have redefined the resolutions of movie-making to become what filmmaker Douglas Trumbull calls 'Hypercinemas' - an evolving notion that begins with Trumbull's late 1970s invention of Showscan, a cinema format that acquires and plays back $70 \mathrm{~mm}$ film at $60 \mathrm{frames} / \mathrm{second}$ to achieve ultra-high resolution in both space and time. ${ }^{4}$

The earliest example of a cinematic multi-projection installation is the ten-projector, 360-degree panoramic screen of the Cinéorama, invented by Raoul Grimoin-Sanson, shown at the Paris Exposition of 1900. The Cinéorama used ten synchronized, $70 \mathrm{~mm}$ film projectors, projected onto ten $9 \mathrm{~m} \times 9 \mathrm{~m}$ screens arranged in a full 360-degree circle, creating a composited image of an immersive cinema experience of a balloon ride. The mechanical photomontage of the Cinéorama was used to create a hyper-realistic, cinematic image.

Abel Gance's film Napoléon of 1927 presents an early illustration of the use of the spatial collage of cells as a dramatic device in cinema. The finale of Gance's film is a triptych sequence in which Gance projected three separate film reels onto three adjacent screens. The scenes move between extra-wide and singular takes that were recorded by three adjacent cameras simultaneously and spatial composites of heterogeneous shots and colour overlays, all to convey the singular narrative (Figure 1).

The first immersive film which used moving, photographic imagery seamlessly covering an entire hemispherical space was shown in 1973 in a specially built theatre, the new OmniMAX format. OmniMAX films were shot using a fisheye lens and an exceptionally large film format ${ }^{5}$ to create live-action images for the dome. OmniMAX remained the dominant immersive format until the rapid development of computer animation techniques and high-definition video in the 1990s contributed to the beginning of fulldome, a 180-degree hemispherical video projection format in a standard planetarium. With the innovations of OmniMax and fulldome, hemispherical projection became cinematic and immersive cinema was born.

4 In a 2012 interview, Trumbull described hypercinemas as 'high frame rates and 3D on the production side with advanced projection tech and curved screens that get brightness up to 30 foot-Lamberts - more than a full stop above the current standard of 14 foot-Lamberts for standard 2D projection, and several stops above the typical brightness at multiplexes for 3D' (Cohen, 2012, para. 4).

5 OmniMAX and IMAX used what is known as a'15-perf', or '15/70', a fifteen-sprocket hole, horizontal piece of 70mm film as opposed to the vertical' 5 -perf', $65 \mathrm{~mm}$ area of standard large format film, providing three times the image area per frame. 

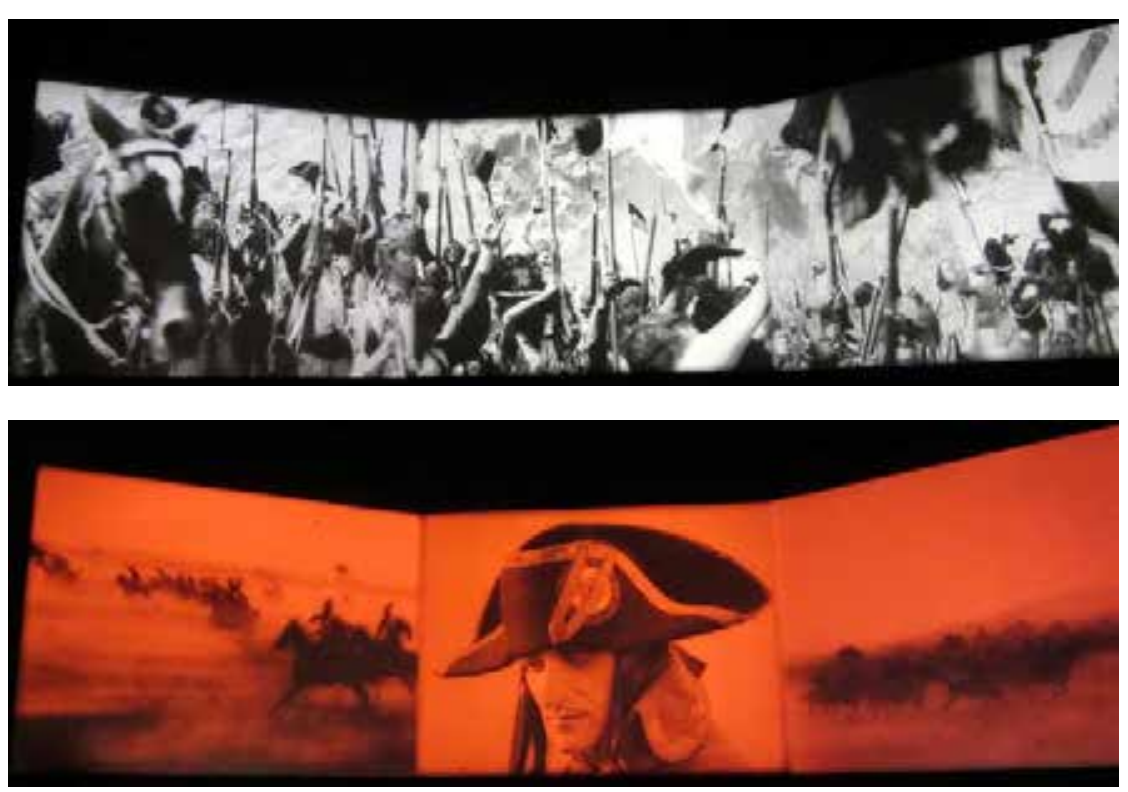

Figure 1. Three views of the finale triptych scene of Napoléon by Abel Gance, 1927, demonstrating the extra-wide singular shot (top), the composite of three heterogeneous shots on three screens (middle), and the graphical use of colour (bottom). ${ }^{6}$

Figure 2 shows a still image from the experimental immersive film Moonwalk (Waite, 2010) where the entire, 60-foot diameter planetarium dome is projected with a photographic image of the full Moon. Moonwalk is a tangible film that takes on the Moon as both its subject and the inspiration for its concrete realization. It represents a form of architectonic cinema, disrupting the division between image space and built space while engaging the audience with the sensuality of an embodied interaction with the narrative structure.

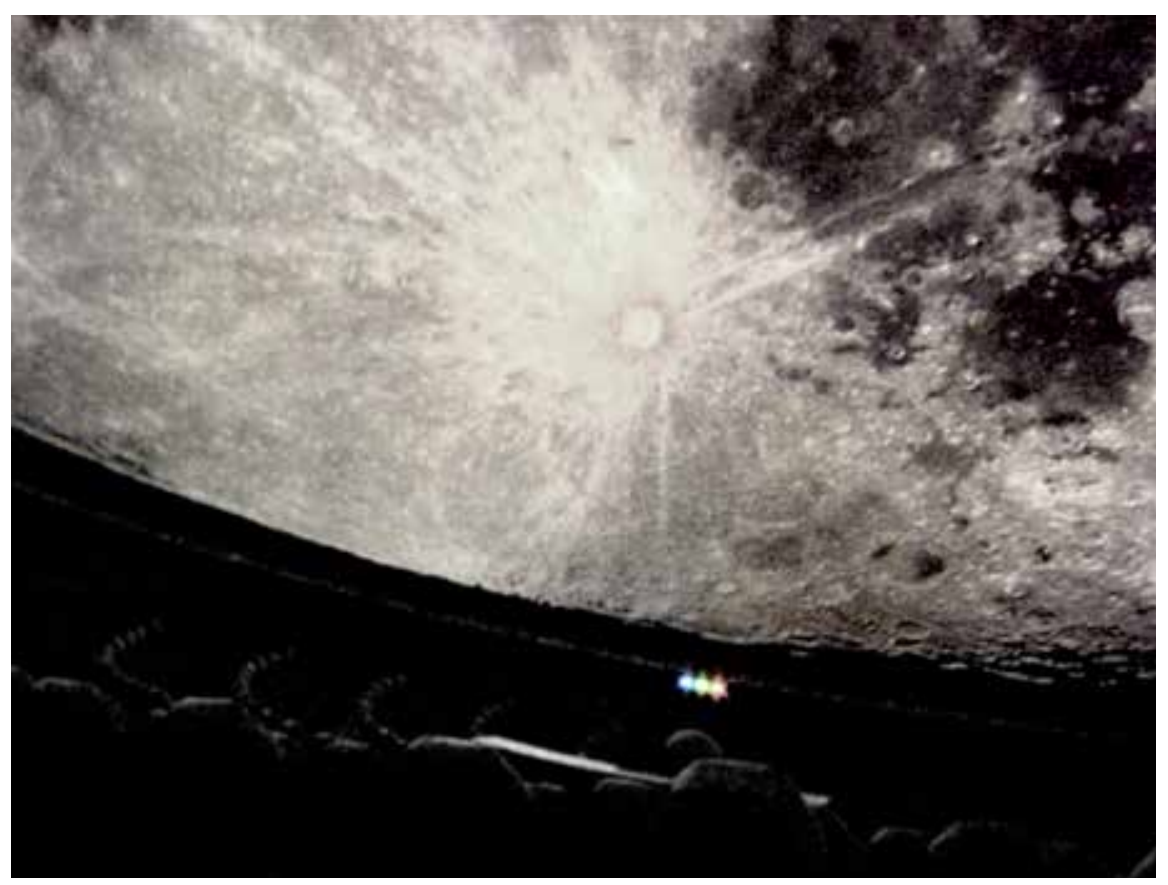

Figure 2. Moonwalk (2010) by Clea T. Waite: fulldome projection at the Adler Planetarium Photo Mark Webb. 


\section{Temporal Montage}

During the silent film era at the beginning of the twentieth century, before the techniques of cinematic montage developed, films were composed of long, static takes. Earliest cinematography mimicked the conventions of theatre and vaudeville, relying on a stationary camera that was placed in the role of the spectator with a view of a complete stage in the original wide shot. Only the actors moved. Silent, these films at the beginning of the twentieth century were often accompanied by a storyteller who narrated alongside them, particularly in Russia where large percentages of the audience were illiterate and so unable to read the intertitles, and in Japan where the narrator was a critical, performative element of the film experience. In Japan, the narrator, known as the benshi, not only narrated the story - reading the intertitles, performing each character, even analyzing the film at times - but also directed the audience's attention, guiding their eyes within a continuous wide shot to focus on specific details on the screen such as a doorway or a window, diverting their eyes around the scene.? These early, narrated, silent films comprising long, static, and wide shots represent a'proto-montage' cinema.

The accomplished stage magician turned film pioneer Georges Méliès invented film editing to facilitate his optical tricks in films such as Voyage dans la Lune of 1902. Méliès made figures magically appear and disappear, the first technical film 'cuts', but he maintained a continuous space in his films. While the attention directing of the Japanese benshi conceives a conceptual precursor to montage, guiding the eyes' point of focus within a continuous space, it is not until the innovations of parallel editing, the intercutting of two simultaneous events, developed by Edwin S. Porter in The Great Train Robbery of 1903, and the invention of the close-up cutaway by D. W. Griffith ${ }^{8}$ in The Lonedale Operator of 1911, that we have the disruption of a logical space-time indicative of the beginnings of true film montage.

The concept of film montage is essential to modern cinematic language. The benshi performed the role of the contemporary motion picture editor, orchestrating the flow of attention by creating close-up details in the mind of the viewer before the technology had evolved to support such cinematic structuring. Like the benshi, the editor, by creating the montage, visually directs our attention through the space and time of a film's narrative. Art and film theorist Rudolf Arnheim describes montage as the distillation of elements and attention: In montage the film artist has a first-class formative instrument, which helps him to emphasize and give greater significance to the actual events that he portrays. From the time continuum of a scene he takes only the parts that interest him, and of the spatial totality of objects and events he picks out only what is relevant. Some details he stresses, others he omits altogether' (Arnheim, 1957: 95).

\section{Constructivist Montage}

The general emphasis in conventional, temporal montage is on producing the impression of a continuous space and time, an unbroken narrative, known as continuity, which reinforces spatial orientation through a non-disruptive, 'invisible' style of edits. The montage strives to provide an organic flow of attention through space and time for the viewer and eschews drawing attention to itself. Parallel to the stylistic developments by Porter and Griffith in early American cinema is the alternative, avant-garde concept of montage that uses a deeply structural and disjunctive structure developed in the Soviet Union in the 1920s. This new development was known as Constructivism or Soviet montage, and film director and theorist Sergei Eisenstein was this movement's most prolific theoretician. Eisenstein

7 See Jess-Cooke, 2012, 28 and 50 n. 44

8 Film historians maintain an open debate as to who first used the close-up in film, but especially Eisenstein acknowledges Griffiths as the first director to develop it into an element of modern cinematic language. See 'Dickens, Griffith and the Film Today' (Eisenstein, 1949a). 
declared 'montage ... the chief means of effect' (Eisenstein, 1949b) for the creation of cinema,'a principally new qualitative fusion, flowing out of the process of juxtaposition' (Eisenstein, 1949b: 238). He argued in favour of a 'disjunctive method of narration', the joining of two shots to yield a new effect or meaning not evident in either shot alone and thereby suggesting an interaction between characters and objects while never including all in the same frame. Eisenstein's core concept for montage rests in this notion of juxtaposition, of placing two disparate shots next to each other in sequence to build new meaning in the mind of the viewer through associations, signified in a conceptual evolution from the individual signifiers of the two shots.

The constructivists' theory of film montage centres on the notion of juxtaposition that occurs between non-continuous elements, what Eisenstein refers to as 'cells', single shots of a film sequence. Eisenstein borrows the notion from biology, explaining his concept of the film cell as an organic building block of the film's totality. 'The shot is a montage cell. Just as cells in their division form a phenomenon of another order, the organism or embryo, so, on the other side of the dialectical leap from the shot, there is montage' (Eisenstein, 1949b: 236).

The cell is a core theme in Eisenstein's theory, and it is central to the conceptual foundation of a somatic montage. The cell represents a graphical (or acoustic or textual) unit that functions within the film less owing to its internal development in time than to the associations that arise when one cell progresses to the next. The juxtaposition that abruptly displaces the viewer in the space-time continuum of the film demands a conceptual leap. Meaning is not gleaned from the contents of a single shot or cell but from the interaction of adjoining cells in time. The mind builds implications from the juxtaposition of divergent image-cells, constructing a message that depends on the interaction of both components. The sequencing of cells is central to constructing the message for Eisenstein: 'In themselves, the pictures, the phases, the elements of the whole are ... indecipherable. The blow is struck only when the elements are juxtaposed into a sequential image' (Eisenstein, 1989: 115).

Film theorist David Bordwell denotes this associative approach through juxtaposition as 'constructivist montage', one that suggests interactions and emotions among characters, objects, and/ or places while never including all the associated elements in the same frame, where 'the joining of two shots yielded an effect or meaning not evident in either shot alone' (Bordwell, 1998: 17). Jean-Luc Godard, the French Nouvelle Vague filmmaker, identifies this recipe for montage with the dynamic compositions of Russian Constructivist photography that appeared in contemporary art at the same time as Eisenstein developed his montage theories in the Soviet Union. Godard writes: '[W] hat made possible the kinds of [Russian] montage ... was the angled shot: the look sharply up, down, or at a tilt so characteristic of Russian avant-garde cinema. ... Renouncing the supposedly "straight" shot ... did not simply energize the frame with dynamic composition, it also announced it as a partial image, just one choice among many' (Campany, 2008: 28). The portraits by artist Alexander Rodchenko (Fig. 3), exemplify the constructivist movement. 


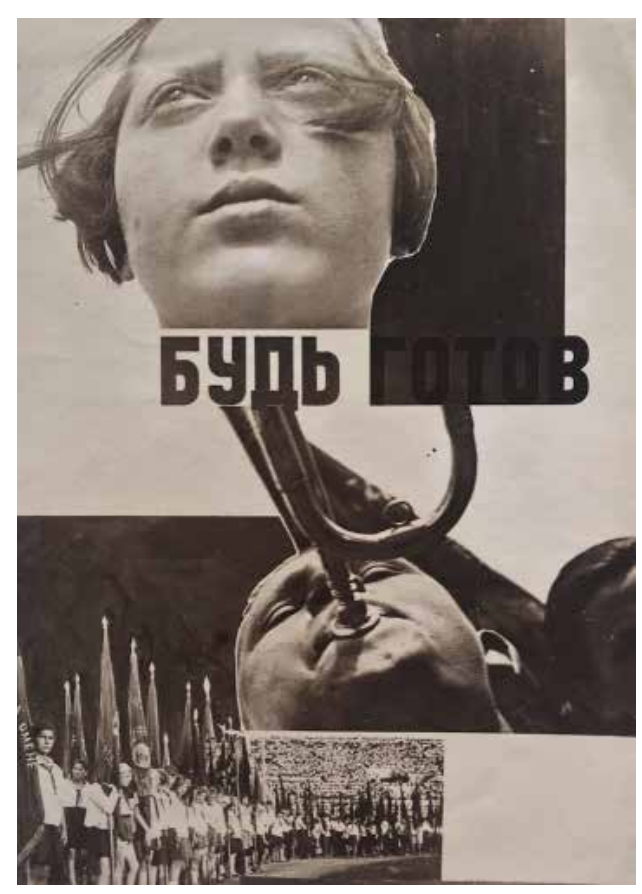

Figure 3. Varvara Stepanova, Bud Gotov (Be Ready), 1934. Photographs by Aleksandr Rodchenko.. ${ }^{9}$

Eisenstein was interested in an energized notion of montage using 'collision' and 'conflict' as his theoretical vocabulary. In Eisenstein's framework, the desired concept to be communicated is constructed in the mind of the viewer, arising from the collision of two different factors. The viewer is a participant engaged with the content to form meaning. Conflict and collision in Eisenstein's sense serve to direct the audience's perception of the narrative through association. These concepts played a role in the notion of disruptive narrative, non-linearity, simultaneity, and ambiguity that were themes arising in the arts - in the cinema, literature, painting, sculpture, and music of the European avant-garde of the same period.

\section{Mise-en-scène}

Film critic and theorist André Bazin developed a counter-notion to Soviet montage in the 1940s, advocating for a more objective reality by defending the long, continuous take and emphasizing composition and action within the deep focus of the image, 'total cinema'. Bazin, like Eisenstein, stressed the importance of interpretation by the spectator, but, in his notion, this occurred by representing a total and complete representation of reality in the mise-en-scène, the design and setting, not through the associations created by the montaged juxtaposition of selected details. Bazin opposed what he considered to be the manipulation of reality represented by avant-garde montage theory. An example of the mise-en-scène approach can be found in the work of director Raoul Walsh, who relished his long, highly detailed, wide-screen landscapes of the American West in The Big Trail from 1930, taking a painterly approach to image complexity and duration. Jacques Tati's Playtime from 1967, with its elaborate sets, intricate action, and long takes, explicitly conforms to Bazin's total cinema, letting layers of action unfold before the camera in very long, single takes. Notably, both directors also worked with the largest and most immersive format of film available to them, $70 \mathrm{~mm}$, relying on this medium's ability to reproduce fine details on the screen. 
The ensuing generation's Soviet filmmaker and theorist Andrei Tarkovski took an approach to cinema that also owes more to Bazin than to Eisenstein. Tarkovski's style is exemplified by the long takes and slow-moving camera in Stalker (1979). In his writing, Tarkovski argues for the precedence of the time within the frame over the successive juxtaposition of shots over time: 'Nor can I accept the notion that editing is the main formative element of a film, as the protagonists of "montage cinema", following Kuleshov and Eisenstein, maintained in the 'twenties, as if a film was made on the editing table .... The idea of "montage cinema" - that editing brings together two concepts and thus engenders a new, third one - again seems to me to be incompatible with the nature of cinema' (Tarkovsky, 1987: 58). For Takovski, Walsh, and Tati, 'montage' is the deep time within the extended and highly detailed image of the shot.

\section{Montage Styles in Immersive Cinema}

Spherical cinema as a medium emphasizes an inherent spatiality over temporality in an immersive cinema experience. Contemporary, mainstream immersive cinema typically adheres stylistically to Bazin's concepts of the mise-en-scène and a total cinema. Immersive cinema experiences, including fulldome films, 360-degree cinema, and virtual reality, tend to be composed of wide, visually detailed, temporally long shots, and use chrono-spatial continuity and linear narrative. Often, there are no edits at all. Flying cameras and virtual roller coasters are common tropes.

In contrast, the genre of experimental cinema, regardless of format, often explores disjunctive space, visual fragmentation, and narrative ambiguity like the avant-garde cinema of the 1920s. Whereas conventional narratives, rooted in literature, tend towards narrative closure, experimental cinema and video art tend towards open-endedness. Media theorist Holly Willis writes of experimental cinema structures: 'Overall, the narratives displayed in video art are often about space, fragments, and the abundance of meaning. Where Hollywood narratives tend to close things down, video art opens things up, dispersing meaning outward, both figuratively and literally, through the multiplication and dispersal of screens' (Willis, 2005: 84). Somatic montage for immersive cinema addresses the evocative, associative, constructivist montage missing in conventional immersive genres where the poetics of a lyrical, avant-garde narrative can emerge from the associations created by spatialized juxtapositions. Eisenstein's notion of juxtaposition is extended in this approach from a temporal montage into a space-time montage.

Beginning in the 1960s, the expanded, experimental cinema movement and video art achieved immersion by using formal constructs such as architectonic space with multiple projections. An early example is the expanded cinema dome installation Movie-Drome (1963) (Figure 4) by artist Stan VanDerBeek. Movie-Drome is a cinematic collage of assorted film projections, originally projected in a planetarium dome. The multiple projections have varying durations, resulting in an aleatoric montage that leaves the specific associations created by the juxtaposition of film cells to chance. The projections disrupt linearity and move the juxtapositions outwards by placing cells across multiple screens in space. Film theorist Gene Youngblood described this emerging new cinematic language as synesthetic cinema. Synesthetic cinema considers the role performed by the design of visual space in the film as an element of meaning, as well as the active role played by the sensate viewer's perception. In Youngblood's definition: 'Synesthetic cinema is an art of relations: the relations of the conceptual information and design information within the film itself graphically, and the relations between the film and viewer at that point where human perception (sensation and conceptualization) brings them together' (Youngblood, 1970: 82). This echoes Eisenstein's notion of the disjunctive method of montage by association. Synesthetic cinema represents a significant tract within the developing syntax of somatic montage for immersive cinema. 


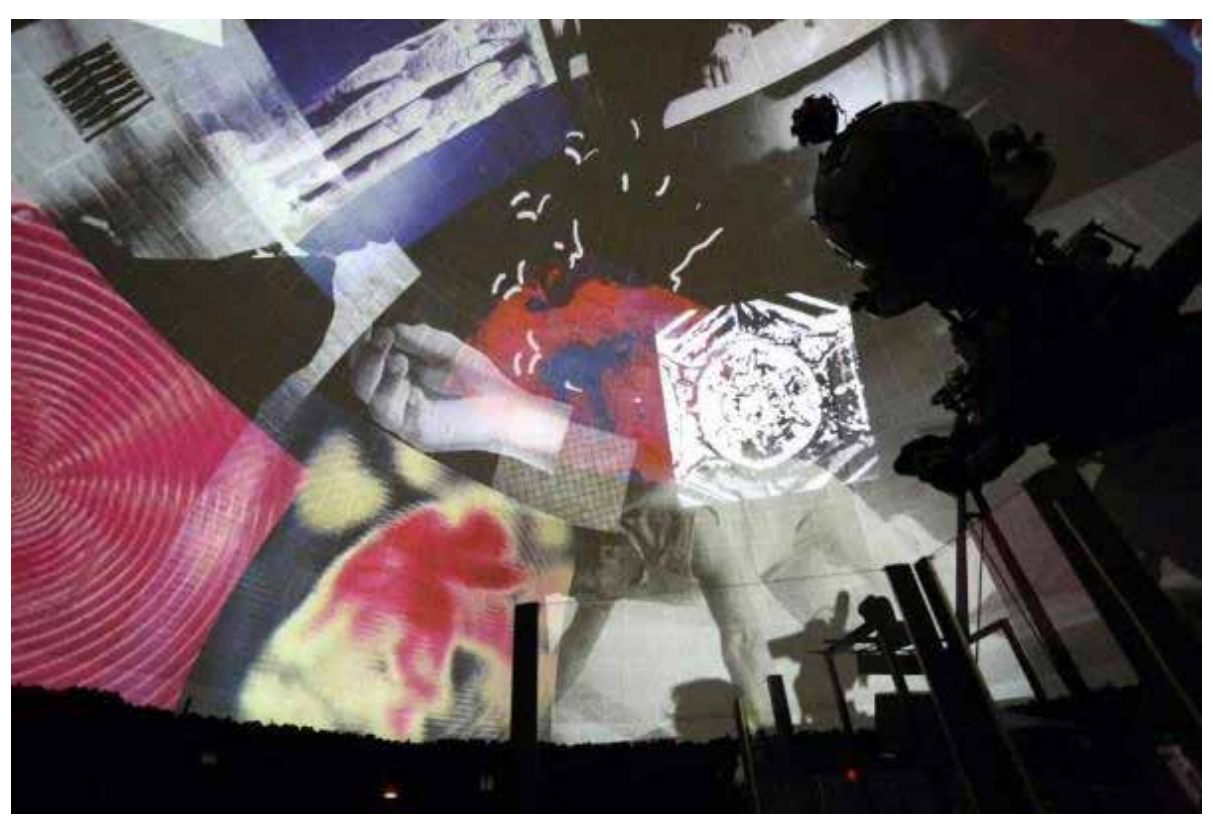

Figure 4. Stan VanDerBeek, Movie-Drome (1963/2014). ${ }^{10}$

\section{Somatic Montage}

The philosophy of phenomenology examines the perception of volumetric forms as the sum of limited views from different perspectives using motion - a time-based phenomenon - around the object to assemble a consciousness of the shape in the mind. Philosopher Maurice Merleau-Ponty described this process of perception as bound up with embodied motion: IIn order to be able to conceive the cube, we take up a position in space, now on its surface, now in it, now outside it, and from that moment we see it in perspective. The cube with six equal sides is not only invisible, but inconceivable ...'(Merleau-Ponty \& Landes, 1962: 204). The same principle applies when animating a three-dimensional cube as a two-dimensional projection onto a motion-picture screen, rendering views over time to overcome the limitations of two-dimensional perspective. In such a rotation, succession subsumes space, revealing hidden faces in a sequence of two-dimensional views to build up a representation of the cube's three-dimensionality in the mind of the viewer.

Somatic montage builds upon a structural foundation rooted in notions of twentieth-century geometric principles. Geometry serves as a formal, objective counterpoint to poetic content constructed through associative collisions. In a somatic montage, form and content, geometry and motion, are inextricably interdependent. This notion of cinema as a poetics of space expands upon Eisenstein's interpretation of architecture as a choreographed narrative of composed views. ${ }^{11}$ The conscious unity of the architectural object relies on the mediation of bodily experience, on physical movement in space. Eisenstein describes montage as a means of traversing spaces and perspectives. Montage links 'various elements (fragments) of a phenomenon filmed in diverse dimensions, from diverse points of views and sides' (Eisenstein, 1989: 11), the theory of 'linkage'.

The distinct gesture of cinema is the ability to connote the instantaneous collapse of space and time between images. Immersive cinema distinguishes itself from conventional cinema viewing practices by fostering a montage of peripatetic, embodied navigation. The tesseract, with its consolidation of three-space and time, provides a model metaphor for constructing a spatio-temporal flow structure

10 VanDerBeek's Movie-Drome was recently updated for the Civico Planetario 'Ulrico Hoepli' Milan in 2014. Image retrieved from VanDerBeek, 1963. Courtesy of Fondazione Nicola Trussardi, Milan and miart 2014, Milan. Photo credit: Marco De Scalzi.

11 See 'Montage and Architecture' (Eisenstein, 1989). 
in an immersive cinema. The immersive architecture that the film projection occupies serves as a factor in its narrative flow. Cinematic elements, cells, are distributed in space as on the facets of a cube. Movement in time by the viewer, through the fourth dimension, provides the connections among these cells which are then assembled in memory to create meaning, like Merleau-Ponty's cube. The observer must navigate through the cinema space using the motion of their body in time to experience all the facets of the tesseract space. In doing so, they experience the information contained within the space as simultaneous media cells occupying its individual faces - faces that can never be seen all at once. They assemble these cells into a unique narrative by engaging their memory to fill in the voids between the spatialized elements as they make their own peripatetic juxtapositions of this physical and conceptual space.

This formal compositional syntax of somatic montage derives from the deconstruction of linear narrative and the hyper-expansion of the two-dimensional image space, allowing for a multidimensional, oneiric re-composition of the parts that actively engages the viewer through movement and memory. Assembling these elements, somatic montage is the formal language motivating the viewer's focus, affording the formation of relationships between signifiers in which it is the viewer's attention that composes the flow of information.

Montage creates a rhythm using the relationship between the beats of the edits in unison with the composition and movement within the image. Visual rhyming arises from juxtaposed correspondences of forms, proportions, planes, colours, expressions of emotion, or directions and speeds of movement around the edit point. Montage is the composition of rhythm and rhyming 'heard' by the eyes. For Eisenstein and Constructivism, cinematic poetry manifests in the collisions of shots based on conflicts of scale, volume, direction, motion, and concepts. For the Soviet filmmakers, the radical innovations of Constructivist montage and other experiments occurred as a historical necessity within the linearity of the film's timeline and the flat plane of the film's image. With somatic montage, the same revolutionary approach to montage can be achieved in a 360-degree film by conceiving of the visible space of the scene - both the diegetic mise-en-scène and the architectonic form of the image space - as a spatial transposition of cinematic time. In immersive cinema, the metric aspect of rhythm created by the chronological beat of image cells in linear cinema can be augmented by the rhythmic movement of the embodied eye across the cinema space architecture. Relations of framing, non-viable in a frameless medium, transpose into relationships of location and distance to the subject. The film cut is supplemented by visual or auditory triggers that motivate the viewer to seek elements outside their current field of view, such as flashes of light that catch in the viewer's peripheral vision, diegetic lures such as guiding characters, or, especially, spatially located sound indicators, essential in a 360-degree vista. Cognition is mediated by the body's movements. The immersive cinema montage is an open, dynamic choreography of subject and object in which the film takes the lead, motivating the viewer's attention into a dance with the film.

\section{Somatic Montage Praxis}

Just as the conjectures of the early avant-garde cinema of the 1920s have become an integral aspect of contemporary film language, we can look to the contemporary avant-garde working in the genre of video art for bold approaches to organizing cinematic narrative in space. Successful examples of immersive, multi-screen video installations in video art that create a new relationship to cinematic space-time for the viewer are found in configurations ranging from a minimum of two up to thirteen screens and more.

The multi-channel video installation came of age in the 1990s with improved video projection apparatuses and the digital enhancement of multiple video sources that could be precisely synchronized in 
an exhibition setting. Artist Shirin Neshat's two-channel video installation Turbulent (1998) uses these technical supports to place the viewer into a dual projection setting, situated in a rectangular room equal in width to the two projection screens. The two screens are positioned opposite, parallel, and facing each other while the viewer enters the space between them (Figure 5). The only open area is directly between the screens, and the only viewing position is facing one or the other screen. Turbulent is a study of binaries - left and right, black and white, male and female, silence and music, isolation and community, movement and stillness, censure and approval. Everything in the video installation reduces to binaries. The framing of the installation architecture plays an equal role in establishing the poetic narrative as the setting of the film.
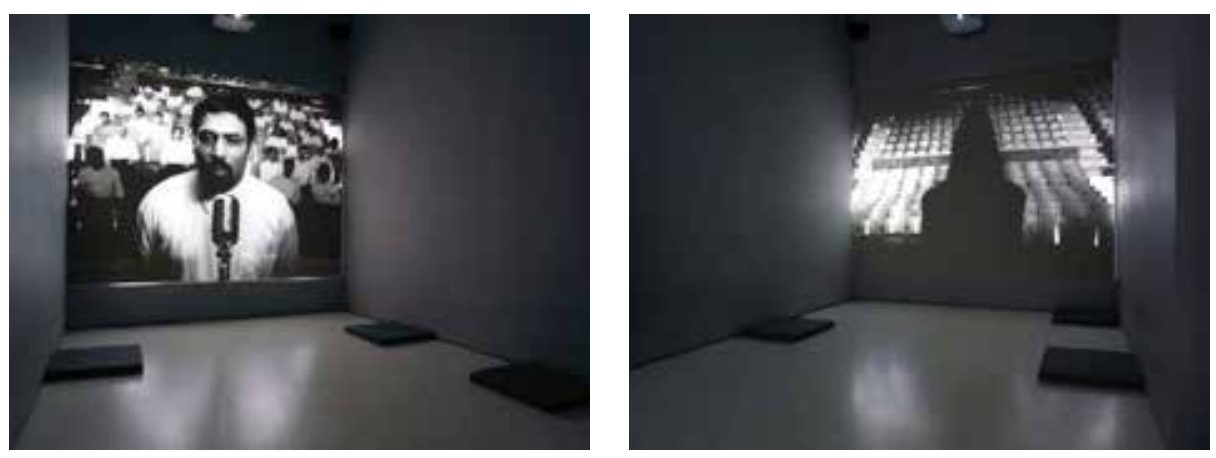

Figure 5. Two views of Shirin Neshat's video installation Turbulent (1998). ${ }^{12}$

Two singers, a man and a woman, take turns singing on a stage. The man, dressed in white, sings to an audience of men; the woman, veiled in black, sings to an empty hall. Neshat creates a parallel montage between the two scenes without cutting. The literal, parallel placement of the screens uses the body of the viewer to 'edit' the juxtaposition of the two streams. Apart from two short edits at the beginning of the film loop, Neshat creates a purely somatic montage of the two uncut sequences. The viewer is placed in a second-person relationship with the film. They must take sides. The installation simultaneously performs a perfect enactment of Eisenstein's 'dialectical montage': thesis juxtaposed with antithesis to yield synthesis. The interrelationship between the space and the film creates a conflict, both physical and metaphysical, in a perfectly reduced poem that conveys Neshat's meaning.

In my experimental fulldome film Moonwalk, I provide an example of the somatic montage approach in an immersive film. A film about the Moon, Moonwalk is projected into the dome of the planetarium. The images of the Moon occupy the round volume of the dome's hemispherical shape. Film and format intertwine form and content. In the film, time-based cells are distributed in a three-dimensional collage across the extent of the image, displaying them simultaneously as well as sequentially in time (Figure 6). The viewer is surrounded by the film - embedded within the film's tesseract. Spatialized sound and peripheral vision guide the eyes around the dome screen. A peripatetic rhythm is created between the viewer's own roving attention and the film's progression. The result is a narrative within a narrative that is lyrical, non-linear, and individual to each viewer, creating what Eisenstein called the 'dual unity', the dialectical relationship between form and content in a film: 'The dialect of works of art is built upon a most curious "dual unity". The effect generated by a work of art is due to the fact that there takes place within it a dual process: an impetuous progressive rise along the lines of the highest conceptual steps of consciousness and a simultaneous penetration by means of the structure of the form into layers of profoundest sensuous thinking. The polar separation of these two lines of aspiration creates that remarkable tension of unity of form and content characteristic of true artworks' (Leyda, 1986: ix). 


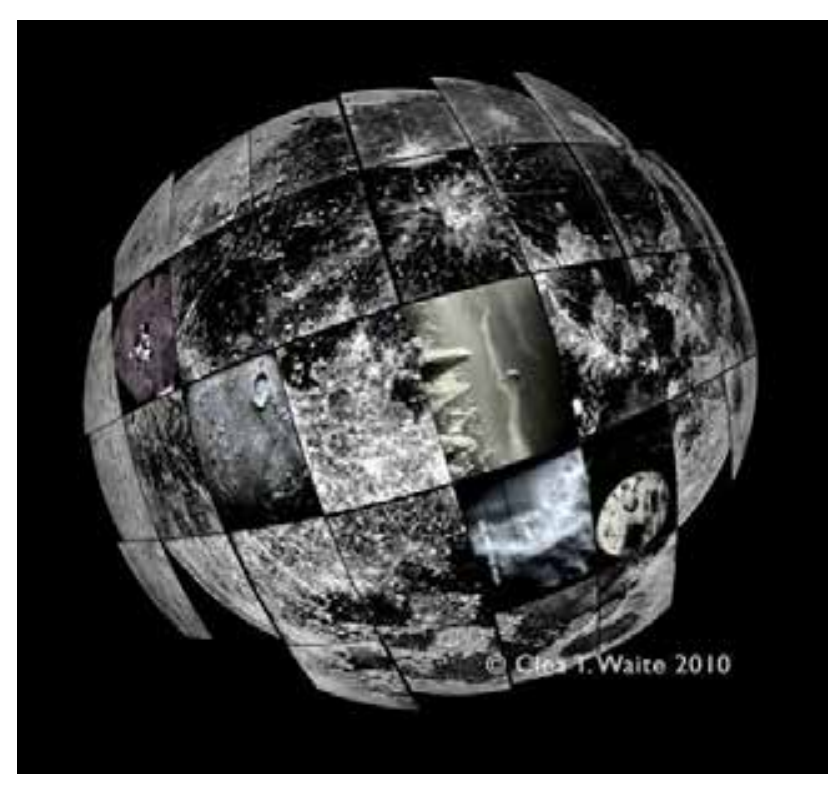

Figure 6. Still from Moonwalk, a fulldome digital film (@ 2010 Clea T. Waite).

The concept of somatic montage is not restricted to cinema. Or, cinema has become a contemporary metaphor for most artistic manifestations that involve framing space and moving through time. In 1997, Catherine David curated the exhibition DocumentaX in Kassel, Germany. For David, the city was her tesseract and the visitors' movements through it the time axis, the fourth dimension of her 'film'. David placed artworks throughout the city, especially along the routes among the exhibition locations. Art critic and theorist Rosalind Krauss analyzes David's cinematic metaphor in Under Blue Cup: 'Catherine David ... planned this procession from train station to exhibition park as a kind of filmic sequence carefully edited with one display juxtaposed to another: a series of jump cuts and dissolves. As she explains it: "Like a film, Documenta is a long and patient process of montage. Working from a more or less coherent script, sequences are isolated and thought out; when their internal structure is established, they are spliced into the whole." Her flow is cinematic ...'(Krauss, 2011: 33-35).

\section{Conclusion}

The historical development of disjunctive montage, faceted perspective, the curvature of space-time, n-dimensional spaces, spatial montage, and disrupted narrative that arose in the twentieth century culminated in a Modernist Zeitgeist that embraces spatial and temporal ambiguity; simultaneity; fragmentation; peripatetic, embodied perception; and a heightened personal participation with a work of art. Somatic montage gathers these impulses into a formal construct for creating a cinema that occupies three-dimensional space and time; an immersive, somatic, proprioceptive cinema that extends the notions of temporal and spatial montage, alternative narrative, simultaneity, and multiple viewpoints into an immersive, formal structure for cinematic art-making.

The notion of somatic montage presented here proposes a broader, multidimensional interpretation of what Eisenstein calls the 'disjunctive method of narration' (Eisenstein, 1949a), made applicable to immersive cinema. The external architecture of the projection space is utilized as an ordering element in the compositional flow of the film, providing the viewer with a conceptual and navigable space in which to build their own field of associations and meaning in the construction of a poetic narrative. Using this construct, the body, with its movements, memory, and sensations, participates in the reading of the immersive cine-poem. 
Somatic montage addresses a growing theoretical concern as immersive cinema gains in status and expands from the highly specialized environments of the planetarium dome and the OmniMAX theatre into the increasingly widespread domains of video installation and virtual reality. It addresses the basic principles of cinematic montage in relation to a three-dimensional, architectonic screen as a spatio-temporal experience, proposing a formal language for poetic composition in these formats. The early twentieth century was a time of exceptional creative experimentation in cinema and the arts, part of the Zeitgeist of the new discoveries being made in geometry and physics at that time. Montage theory and contemporary cinematic language are some of the legacies of this experimentation. Comparable formal experiments in montage are now emerging in immersive cinema media, diverging from the mise-en-scène approach reminiscent of the earliest films and Bazin's total cinema into a more disjunctive method of montage as developed by Eisenstein and the proponents of Constructivist montage. The tesseract, the geometric embodiment of three-dimensional space in combination with the fourth dimension of time, provides a model metaphor for a new approach to disjunctive montage in immersive cinema. This strategy promises a rich practice of immersive, somatic cinema that formally engages a supra-dimensional approach to participatory interaction between film and viewer in forming meaning. The engaged body, memory, and the expansion of the cinematic experience into a navigable space of simultaneous presentations and ambiguous interpretations unlock the potential for a more associative, proprioceptive sensibility towards creating a poetic, immersive, cinematic experience.

\section{Commentary by Szilvia Ruszev}

Clea von Chamier-Waite eloquently brings together a historical outlook into early twentieth-century film, art and science innovations, creating a case for a cultural paradigm shift with far-reaching consequences, influencing a contemporary approach of theorizing immersive cinema. Her paper 'Somatic Montage for Immersive Cinema'centres on the notion of montage, rooted in the ground-breaking work of Eisenstein and his idea of meaning created by the juxtaposition of separate shots. Somatic montage offers a new language of immersive cinema - in Chamier-Waite's terms, it marries chronological and spatial composition in the creation of narrative.

She situates the emergence of the idea of somatic montage at the beginning of the twentieth century, at the dawn of ground-breaking scientific discoveries such as non-Euclidean geometry, the Theories of Relativity, and quantum mechanics, the flourishing of the avant-garde with its conventions breaking formalism, and the early years of cinema in which editing, as such, found its formal language. The overall cultural paradigm shift that is present in all these areas points at a departure from a monolithic, objective, and central perspective towards a fragmented, ambiguous, and heterogenic worldview. The tesseract becomes the working metaphor to understand the principle of somatic montage as a four-dimensional, spatio-temporal structure that enfolds the viewer in an embodied, relational, and fragmented manner.

The aspiration to approach immersive cinema from the perspective of somatic montage is to acknowledge the poetic and critical potential of cinema as a four-dimensional work and to offer a systematic language with which to understand and create immersive cinema. Instead of looking at the examples of immersive cinema as continuous spaces, Chamier-Waite is rather interested in the poetic capacity that lies in the embodied discontinuity of perceiving these spaces in time and the meaning that arises from the interaction between these immersive spaces and the viewer. The way she uses the term immersive cinema spans a wide historical arc in which mixed reality - being discussed as emerging media - finds its place in a succession of various expanded and immersive forms of media 
such as early examples of immersive spaces, early split-screen cinema, fulldome cinema, and video installations. This approach allows one to move away from a focus on technological advancement and rather engage in a more holistic and historically interconnected view centring on the notion of embodiment and an expanded participatory understanding of montage.

The idea of somatic montage incorporates a historical perspective while simultaneously offering a praxis for contemporary four-dimensional media both in its physical and virtual forms. Reading Chamier-Waite's paper offers an intriguing perspective on the embodied and poetic capacities of immersive media for a wide range of fields such as cinema and media studies, art history, cognitive sciences, media art, and architecture.

\section{References}

Albanese, M. 26 September 2016. Napoleon di Abel Gance di nuovo in sala dall'11 novembre. Stanze di Cinema. https://stanzedicinema.com/2016/09/26/napoleon-di-abel-gance-di-nuovoin-sala-dall11-novembre/.

Arnheim, R. 1957. Film as Art. University of California Press.

Bordwell, D. 1998. On the History of Film Style. Harvard University Press.

Bragdon, CF. 1915. Projective Ornament. The Manas Press, Rochester, NY.

Campany, D. 2008. Stillness. In Photography and Cinema. Reaktion Books, 22-59

Chamier-Waite, Cv. 2013. The Cine-Poetics of Fulldome Cinema. In Animation Practice, Production \& Process (Vol. 3). Intellect Journals, 219-33.

Chamier-Waite, Cv. 2019. Somatic Montage: Supra-dimensional Composition in Cinema and the Arts. Dissertation, University of Southern California.

Cohen, DS. 16 February 2012. Trumbull Lights Up 'Hypercinema'. Variety. https://variety.com/2012/ film/columns/trumbull-lights-up-hypercinema-1118050369/.

Eisenstein, S. 1949a. Dickens, Griffith and the Film Today. In Film Form: Essays in Film Theory. Harcourt Brace, 195-256.

Eisenstein, S. 1949b. Film Form: Essays in Film Theory (trans. J. Leyda). Harcourt.

Eisenstein, S.1989. Montage and Architecture (trans. M. Glenny). Assemblage, 10, 111-31. DOl: doi.org/10.2307/3171145.

Finkelstein | S/TUDIO, C. 4 February 2017. Napoleon by Abel Gance. SOME/THINGS. https://www.someslashthings.com/online-magazine/2017/1/30/napoleon-by-abel-gance.

Giedion, S. 2009. Space, Time and Architecture: The Growth of a New Tradition, Fifth Revised and Enlarged Edition (revised edition). Harvard University Press.

Jess-Cooke, C. 2012. Film Sequels: Theory and Practice from Hollywood to Bollywood (reprint edition). Edinburgh University Press.

Krauss, RE. 2011. Under Blue Cup. The MIT Press.

Leyda, J. (Ed.) 1986. Eisenstein On Disney - A Classic Book (trans. A. Y. Upchurch). Seagull Books.

Merleau-Ponty, M. and Landes, DA. 1962. The Spatiality of One's Own Body and Motility. In Phenomenology of Perception. Routledge \& Kegan Paul, 98-148.

Neshat, S. 1998. Turbulent [two-channel video projection: LaserDisc transferred to DVD (black and white, sound)]. https://coleccion.caixaforum.com/en/obra/-/obra/ACF0681/Turbulent.

Stepanova, V. 1934. Bud Gotov (Be Ready). Vintage gelatin silver photomontage. https://www.nailyaalexandergallery.com/exhibitions/soviet-photomontage-1920s-1930s/selected-works\#inquire.

Tarkovsky, A. 1987. Sculpting in Time: Reflections on the Cinema. University of Texas Press. 
VanDerBeek, S. 1963. Movie Drome: Cine Dreams at Civico Planetario 'Ulrico Hoepli'. https://hammer. ucla.edu/programs-events/2016/03/failure-as-a-generative-process-expanded-cinema-experiments-of-stan-vanderbeek/.

Waite, CT. 2010. Moonwalk [experimental; fulldome]. Carl Zeiss AG, Planetarium Section, Jena Germany.

Youngblood, G. 1970. Expanded Cinema. Dutton.

\section{Authors information}

Clea von Chamier-Waite, $\mathrm{PhD}$ is an intermedia artist, experimental filmmaker, scholar, and engineer whose artworks investigate the material poetics that emerge at the intersection of art, science, and technology. She creates immersive, cinematic works engaging embodied perception, dynamic composition, and sensual interfaces - as well as one inter-species collaboration with several hundred tropical spiders. Her artistic themes examine climate change, astronomy, particle physics, history, feminism, and popular culture. Chamier-Waite received her PhD from the University of Southern California in interdisciplinary Media Arts + Practice, writing her dissertation on the development of somatic montage from early twentieth-century scientific discoveries and artistic innovations. She has been a Humboldt Fellow, a Radcliffe Fellow, a CERN artist-in-residence, an Immensiva artist-in-residence, and a Fellow at the Academy of Media Arts Cologne. Chamier-Waite has held positions at the Academy of Film and Television Babelsberg, Pratt Institute, New York, and the University of the Arts, Berlin.

Szilvia Ruszev is a media artist, scholar and film editor working with moving images in various forms. She is interested in montage theories, sensual knowledge and politics of post-cinema. Her awardwinning work has been part of numerous international film festivals and exhibitions such as Karlovy Vary IFF, TIFF Toronto, Berlin IFF, Siggraph, Codame and Femmebit. She is a PhD fellow at the Media Arts + Practice Program at the University of Southern California.

\section{○ \\ OPEN ACCESS}

Copyright: @ 2021 The Author(s). This is an open-access article distributed under the terms of the CreativeCommons Attribution 4.0 International License (CC-BY 4.0), which permits unrestricted use, distribution, andreproduction in any medium, provided the original author and source are credited. See http://creativecommons.org/licenses/by/4.0/. 